\title{
Ectopic Glial Tissue in the Occipital Scalp*
}

\author{
FREDERICK E. JACKSON, and B. S. MOORE \\ From the Department of Neurosurgical Surgery and the Department of Pathology, Naval Hospital, Camp Pendleton, \\ California, U.S.A.
}

\section{Case Report}

A newborn female infant was admitted to the Neurosurgical Service, Naval Hospital, Camp Pendleton, California, in January 1968. The child had been born with a flat, dark-red lesion in the occipital scalp, very slightly to the left of the midline near the inion. The lesion was slightly depressed from the surrounding scalp and contained no hair. It was not tender. The dark reddish colour did not blanch with finger pressure. Bone was palpable under the defect and there was no visible sinus tract (Fig. 1).

Skull $x$-rays were normal. In particular, there was no evidence of a bony defect underlying this lesion.

A tentative diagnosis of ectodermal dysplasia of the scalp was made, with the possibility that this might represent the dysplasia overlying an intracranial dermoid. On the third post-partum day, excisional biopsy of the lesion was performed. It was seen to be completely free of the skull and, upon very careful dissection, there was no stalk extending to the skull. A small burr hole was made in the skull underlying the lesion, and the dura was inspected and opened to make sure there was no underlying dermoid. There was none. The dura was closed and the scalp was brought together easily and closed with 4-0 dermalon. The wound healed by first intention and the child has since remained neurologically normal, as she was before the examination.

Histological examination of this material revealed sections of skin with a depressed area in the centre of the tissue (Fig. 2). Under this region, the adnexal structures were decreased or totally absent. To each side of the lesion were numerous hair follicles, sebaceous glands, and sweat glands, and within the lesion were collections of glial cells partially surrounded by leptomeninges. At the bottom of the tissue there was a small rim of collagenous connective tissue surrounding the glial tissue and meningeal tissue. One piece of skin revealed ulceration of the surface with infiltration of polymorphonuclear leucocytes and some fibrin. No ganglion cells were found in the lesion (Fig. 3). The ectopic tissue was located completely within the dermis and subcutaneous tissue. There was no evidence of malignancy.

Received November 15, 1968.

* The opinions contained in this paper are those of the authors and not to be construed as official or reflecting the views of the Navy Department or the Naval Service at large.

\section{Discussion}

This case is worth recording because unlike the usual 'encephalocele', a bulging lesion appearing either at the base of the nose (the so-called sincipital variety of encephalocele) or the basal variety presenting within the nose, pharynx, or orbit, this heteropic glial tissue appeared as a flat, sessile lesion. Hence, in appearance it did not resemble the usual encephalocele, and the finding of glial tissue microscopically was a surprise.

In addition, careful examination of serial sections revealed no ganglion cells, though glial cells were abundant. One similar case has been reported by Lee and McLaurin (1955), and in their case, the single lesion was also located in the occipital scalp. Their case, presenting in a 1-year-old white female infant, was also found to have been composed of astrocytes without recognizable ganglion cells. Neither Anderson (1947), Berger (1890), Bratton and Robinson (1946), Davis (1942), Miller and

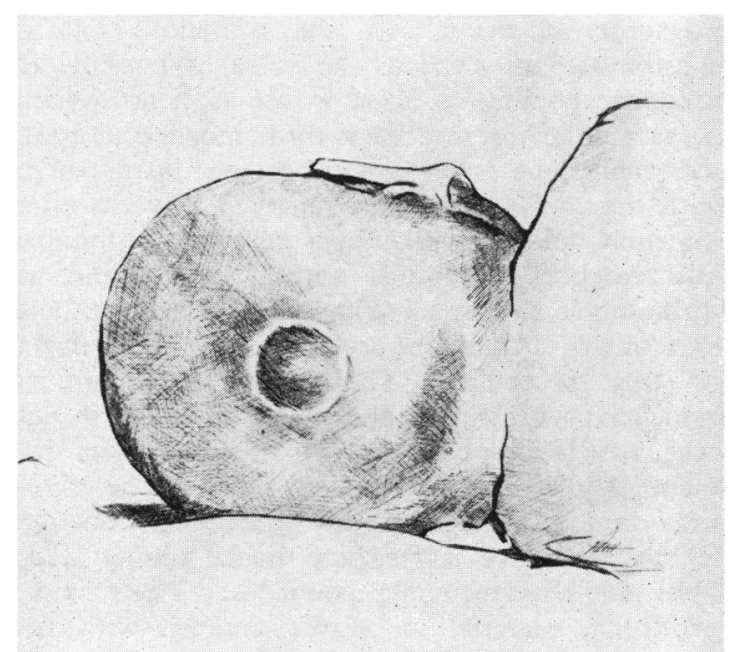

Fig. 1.-Artist's sketch of flat, round, reddish lesion near inion in newborn infant, which on excisional biopsy proved to contain heteropic glial tissue. 


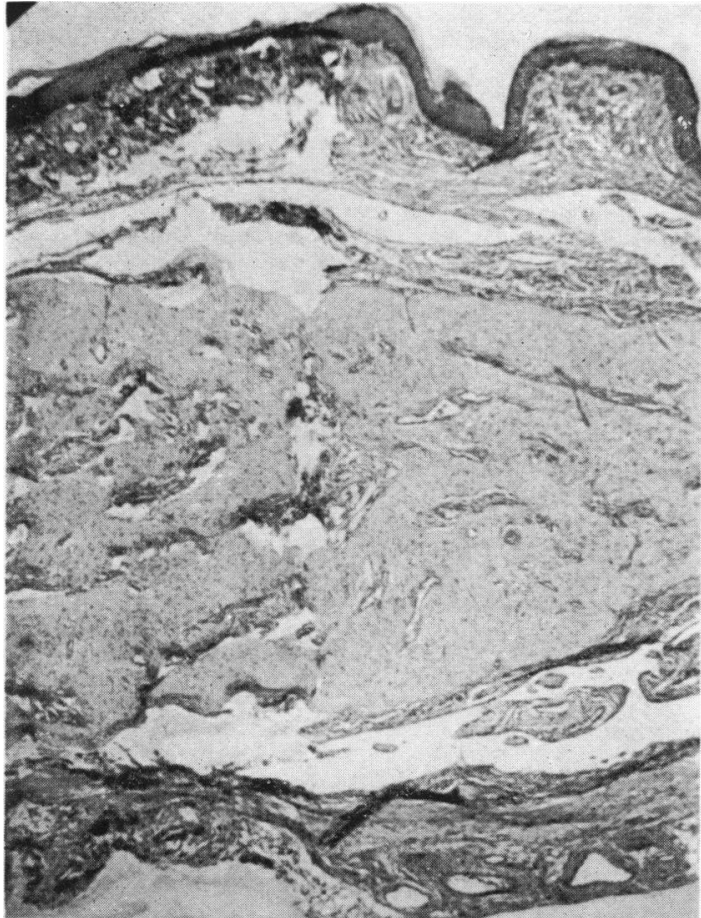

FIG. 2.-Ectopic glial tissue within the dermis of the occipital scalp. Complete absence of adnexal structures underlying the centre of the lesion. Bottom of the lesion is lined by meningeal tissue. $(H$. and $E . \quad \times 30$.
Neidhardt (1950), Neufeld (1895), nor Schmidt (1900) were able to demonstrate ganglion cells in their reported cases of 'encephaloceles'. As an abnormal encephalocele is most probably formed sometime bctween the third and fifth week of embryonal development, we submit that if, as Schmidt (1900) postulated, an encephalocele tumour represents a bud of brain 'nipped off', then one would expect that this nipped-off portion of encephalon should manifest either neurones or 'ghost' cells representing the site of degenerated neurones. The only alternative possibility is that the neurones, having been deprived of their axonal connexions, have undergone trans-synaptic degeneration. However, the absence of neurones in encephaloceles that have a persistent connexion with the brain militates further against that theory. It is postulated, therefore, that rather than a 'nipped-off' portion of encephalon that has been isolated between the third and fifth week of embryonal development, 'encephaloceles' and 'nasal gliomas' represent heteropic glial rests. In no instance has there been invasion of surrounding tissue nor metastases, and hence these lesions do not act as malignant tumours.

\section{Summary}

The case is reported of a flat, sessile, occipital lesion in a newborn infant that, on histological examination after excisional biopsy, proved to be

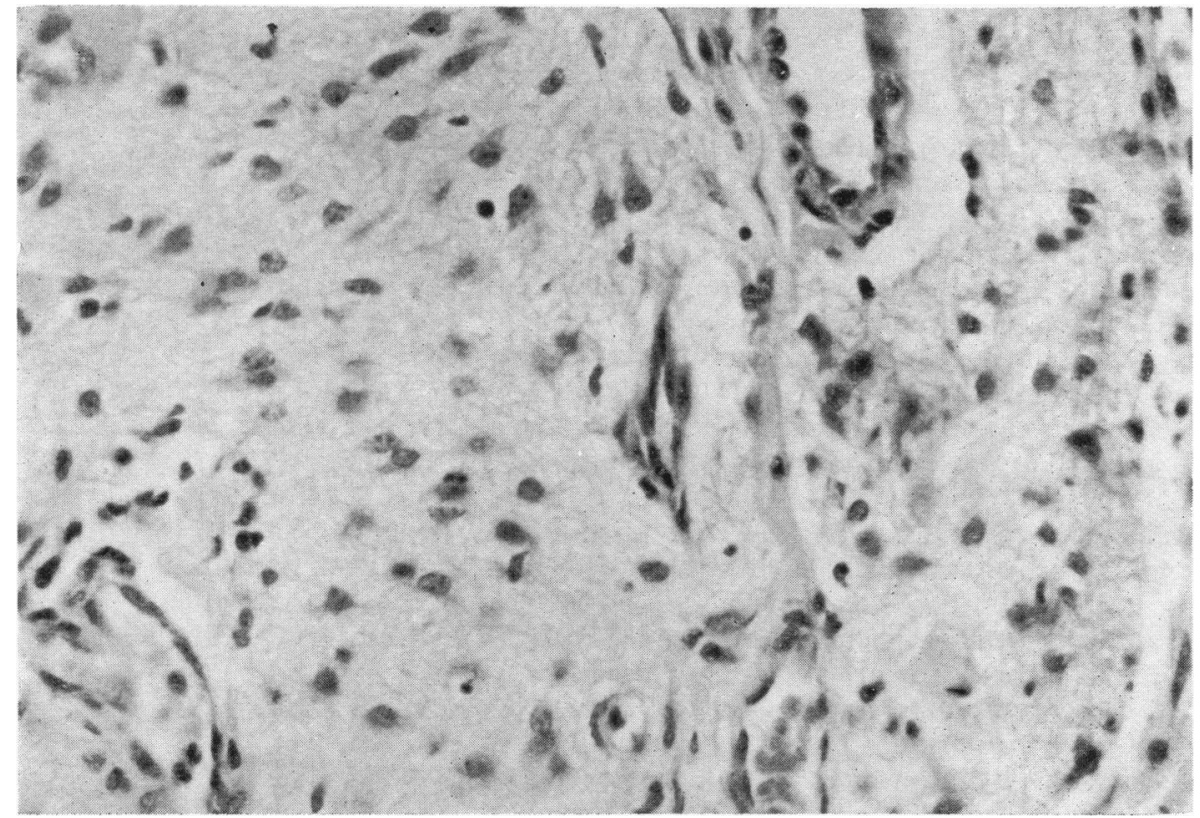

Fig. 3.-High-power photomicrograph showing abundant glial cells in the centre of the occipital scalp lesion. Note the complete absence of neurones. (H. and $E . \quad \times 400$. 
composed of glial tissue surrounded by meningeal tissue without evidence of neurones or ganglion cells. In view of the lack of ganglion cells in this case and other similar cases, it is suggested that these lesions do not represent 'nipped-off' bits of encephalon isolated during the third to fifth week of embryonal development, but rather heteropic meningoglial rests.

\section{REFERENCES}

Anderson, F. M. (1947). Intranasal (sphenopharyngeal) encephalocele. A report of a case with intracranial repair and a review of the subject. Arch. Otolaryng., 46, 644.

Berger, P. (1890). Considérations sur l'origine, le mode de développement et le traitement de certaines encéphalocèles. Rev. Chir. (Paris), 10, 269.
Bratton, A. B., and Robinson, S. H. G. (1946). Gliomata of the nose and oral cavity: a report of two cases. $\mathcal{F}$. Path. Bact., $58,643$.

Davis, E. W. (1942). Gliomatous tumours in the nasal region. f. Neuropath. exp. Neurol., 1, 312.

Lee, C. M., Jr., and McLaurin, R. L. (1955). Heterotopic brain tissue as an isolated embryonic rest. $\mathcal{f}$. Neurosurg., 12, 190.

Miller, G. V., and Neidhardt, H. W. (1950). Extranasal type of nasal glioma. F. Pediat., 36, 798 .

Neufeld, F. (1895). Beitrage zur Kasuistik der angeborenen Schadelgeschwulste. Beitr. klin. Chir., 13, 730.

Schmidt, M. B. (1900). Ueber seltene Spaltibilungen im Bereiche des mittleren Stirnfortsatzes. Virchows Arch. path. Anat., $162,340$.

Correspondence to Commander F. Jackson, U.S. Naval Hospital, Camp Pendleton, California 92055, U.S.A.

The following articles will appear in future issues of this Journal:

Dysplasia Spondyloepiphysaria Congenita and Related Generalized Skeletal Dysplasias Among Children with Severe Visual Handicaps. By G. R. Fraser, A. I. Friedmann, P. Maroteaux, A. M. Glen-Bott, and U. Mittwoch.

Association Between Pneumomediastinum and Renal Anomalies. By M. M. Liberman, J. M. Abraham, and N. E. France.

Recurrent Haematuria in Childhood. A Five-year Follow-up. By Carden Johnston and Stanton Shuler.

Neonatal Drug Depression and Respiratory Distress Managed by Positive Pressures Ventilation and Exchange Transfusion. By J. A. Young and S. Rasheed.

Persistent Proteinuria in Children. By Y. C. Tsao, W. C. Chan, and J. B. Gibson.

Selectivity of Proteinuria in Childhood Nephrotic Syndrome. By David R. Lines.

Urinary Hydroxyproline: Creatine Ratio in Normal Term, Preterm and Growth-retarded Infants. By M. K. Younoszai, Anne Kacic, Louise Dilling, and J. C. Haworth.

Small Intestinal Lymphangioma. By J. A. Walker-Smith, R. D. K. Reye, G. B. Soutter, and K. G. Kenrick.

Plasma Histamine Levels During the First Week of Life. By L. V. Cooper, D. R. Harvey, and J. A. Davis. Long-term Prognosis After Major Resection of Small Bowel in Early Infancy. By Winifred F. Young, Valentine A. J. Swain, and Elizabeth M. Pringle.

Primary Malignant Reticulosis of the Brain in Wiskott-Aldrich Syndrome, Report of a Case. By Michael M. Brand and Vincent A. Marinkovich.

Factors Influencing Exposure of Children to Lead. By Donald Barltrop and N. J. P. Killala.

Retinal Photography in the Newborn. By C. J. Bulpitt and J. D. Baum.

Distribution of Malarial Antibody in Maternal and Cord Sera. By A. I. O. Williams and H. McFarlane. The Metacarpal Index of Infants. By M. C. Joseph and S. R. Meadow.

Auto-immune Thyroid Disease in Children with Mongolism. By Dagfinn Aarskog.

Insulinoma in Childhood. By Jillian R. Mann, P. H. W. Rayner, and A. Gourevitch.

A Case of Mild Hyperparathyroidism in Childhood. By S. C. Latham, Ph. Bordier, F. H. Doyle, F. D. Higgs, G. F. Joplin, Selwyn Taylor, and N. C. Thalassinos.

An Infant with Both Cystic Fibrosis and Coeliac Disease. By David W. Hide and David Burman.

Measurement of Pyuria in Urinary Tract Infections. By I. B. Houston.

Cervico-oculo-acusticus Syndrome with Pseudopapilloedema. By T. H. Kirkham. 